\title{
Comparative Study on Modern Ceramic Art in China and the West Based on Cultural and Psychological Differences
}

\author{
Zibo Lin ${ }^{1, *}$ Xiaodie Shi ${ }^{1}$ \\ ${ }^{1}$ Xiamen Academy of Arts and Design, Fuzhou University, Xiamen, Fujian, China \\ *Corresponding author. Email: 1039215135@qq.com
}

\begin{abstract}
No universal concept and connotation of modern ceramic art have formed among Chinese ceramic art circle. A glimpse of modern ceramic art in China and the West reveals contrast in ideas expressed, material, language and aesthetics, which can mostly be explained by their difference in culture and psychology. Proceeding from reality and taking modern ceramic art of China and West since China's reform and opening up as research object, the paper studies their difference in modern ceramic art creation caused by culture and psychology, as well as the transformation of Chinese ceramic art creation from traditional to modern, in a bid to innovate the development path of modern ceramic art.
\end{abstract}

\section{Keywords: modern ceramic art, differences between China and the West, ceramic art}

\section{INTRODUCTION}

Ceramic art has always been an integral part of Chinese culture. For thousands of years, it has been accompanying the people living on this land, participating in people's lives, and witnessing the rise and fall of imperial dynasties. Despite its splendid history, Chinese ceramic art is still relatively immature compared with that of the West. China is a late comer to western countries, even South Korea and Japan in this aspect. The concept of modern ceramic art has long been controversial in China. Unlike traditional ceramic art, modern one proposes a brand new interpretation of ceramic materials, which values more the expression of thoughts and emotions, and the exploration other than skills.

The concrete manifestation of modern ceramic art, a new art form, varies with the region and the era. In the 1950s, modern ceramic art revolution broke out in Japan and the United States successively, which blazes new trail. The "Otis Ceramic Art Revolution" in the United States lifted the shackles of arts and crafts and injected new vitality, marking the beginning of modern ceramic art in America. At the same time, Sōdeisha was founded in Japan, whose founders Kazuo Yagi (やぎかず お) and Osamu Suzuki emphasize compliance to one's heart in the creation of ceramic art, and skills not restricted by practicality. As a result, ceramic art has become a pure art that values spiritual and emotional interpretation rather than practicality. China's reform and opening up in the 1980s brought a swath of western modern artistic concepts and forms, as well as cultural exchanges of various styles and schools of thought, which greatly hit China's art creation and prompted the rapid development of China's modern ceramic art. All aspects of Chinese ceramic art are influenced by western counterpart. As to the scope of creation, ceramic art forayed into fields beyond arts and crafts, and traditional ceramic art are enriched. As for creators, influenced by western modern culture and art, creation subject has changed from the collective to the individual. More and more well-educated artists and "academics" have engaged, and the division between "craftsman" and "artist" has become more obvious. In terms of creation concept and method, modern ceramic art focuses more on individuation and individual cognition, material exploration, etc., instead of taking exquisite craftsmanship, delicate works and restoration of tradition as standard. The distinction between art and craft is emphasized, and the artistic features and aesthetic style of works also transformed from classical to modern. According to Discussion on Contemporary Chinese Ceramic Art by Bai Ming, "it is natural to draw lessons from foreign ceramic art to develop China's modern ceramic art given the concept of ceramic art is introduced to China." ${ }^{1}$ Since the 1980s, China's modern ceramic creation, which had ended its blind pursuit of the West, has fully absorbed foreign artistic nutrients and embarked on a new stage of modern ceramic art with national aesthetics.

The history of modern Chinese ceramics has witnessed the contributions of a large number of

Bai Ming. Discussion on Contemporary Chinese Ceramic Art [J]. Art \& Design. 1999.02.03. 
ceramists and artists, whose attempts in style, genre and technique have promoted its development. Zhu Danian initiates a decoration pattern of Chinese style with new decorative language; Yao Yongkang's freehand brushwork of characters is both skillful and elegant; Zhou Guozhen's animal sculptures are unique and special; and Chen Songxian's expressive ceramics integrate tradition and originality. In addition, $\mathrm{Li}$ Zongmao brought into China the advanced ceramic art information he has learned abroad; Zuo Zhengyao spared no effort to incorporate modern Chinese ceramics into museum's academic activities; Li Jianshen introduced representative contemporary American ceramists to China and established a platform for communication; and Bai Ming has been promoting international dialogue for several years and has truly recorded the development of modern ceramics. The introduction of foreign ceramic creation concept has made Chinese modern ceramic art break away from the fetters of tradition, embrace diversity, and better the overall landscape of Chinese modern ceramic art, thus promoting the development of Chinese modern ceramic art

\section{ANALYSIS OF DIFFERENCES BETWEEN CHINA AND THE WEST}

\section{A. Cultural and psychological differences between China and the West}

In History of Chinese Philosophy, Feng Youlan clearly and generally distinguishes between Eastern and Western civilizations, that is, the Eastern culture originates from agricultural civilization, while the Western culture from marine civilization. The difference in origin result in varied national character, which leads to contrast of the two in values, ways of thinking, ways of expression and so on. In terms of values, China upholds morality, abides by etiquette and laws, and pursues harmony between man and nature, while the West pursue exploration, adventure, and personality publicity. Chinese civilization advocates collective spirit, while Western civilization emphasizes individual development. As for the way of thinking, Chinese prefer abstract thinking or perceptual thinking, which is emotional and intuitive. while Westerners prefer logical thinking or rational thinking. The Chinese, who prefer comprehensive thinking, probe into the relationship between things. They believe in "unity", in which heaven, earth and human beings live in harmony with each other. Westerners who prefer analytical thinking reflect on the nature of things. They pursue the meaning of individual survival, and unconventional thoughts is relatively common. Artistic creation is also influenced by the way of thinking. For example, Taoist thoughts can be found everywhere in traditional Chinese paintings, while rationality and restraint are revealed in western sculptures. As for the way of expression, Chinese are implicit and euphemistic, while Westerners are bold and direct. The main difference in artistic creation lies in the follows. Traditional Chinese art is freehand, while western classical art is realistic. Imagination is crucial to Chinese artistic creation. For example, Chinese landscape paintings with scattered perspective transform the concrete into abstract through imagination, and express the image the creator intended to convey through image modeling, thus letting off the ideal beauty. In the West, realism is emphasized. Artistic creation is based on copying reality, and accurate proportion, perspective and anatomical relations, in which scientific research and artistic creation reinforce each other. Leonardo Da Vinci is a representative. To sum up, the differences in art forms between Chinese and Western are down to creators' own cultural psychology, that is, perceptual thinking and rational thinking.

\section{B. The difference in modern ceramic art creation between China and the West}

A review of modern ceramic art in China and the West shows distinction in ideas expressed, material, language and aesthetics, which can mostly be chalked up to their difference in culture and psychology. Given the background of China's construction of a strong country in culture, in-depth analysis of the differences between the two goes a long way towards the development of modern ceramic art with Chinese characteristics. In terms of ideas expressed, modern ceramic art in the West focuses on the abstract expression of concrete things and deeply explores the material expression charm and spiritual aesthetic quality of ceramic materials. Modern ceramic art of China attaches great importance to emotional expression of concrete things and employs material language to express spiritual life and cultural emotion. The culture and emotion are interwoven in Chinese modern ceramic art, and the creators pay attention to spiritual civilization and inner emotion. Radical change and renewal of ideas caused by western modern art leads to great change and development of aesthetics and form. Alfied Krupp and Kluckhohn, American anthropologists, once mentioned that "culture exists in various patterns of explicit and implicit. It's taught and circulated by means of the movement of symbols, and constitutes the special achievement of human groups." 2 Therefore, it is feasible to understand the cultural psychological factors behind Chinese traditional themes from the perspective of cultural symbols. Chinese traditional culture contains a wealth of artistic creation themes, including historical stories, celebrity allusions, themes that imply good life and beliefs about blessing. Yao Yongkang's Century Doll ("Fig. 1") imitates the

\footnotetext{
2 Shao Dazhen. Western Modernist Art Thought [M] Sichuan Fine Arts Publishing House, 1992.
} 
image of a lucky boy in traditional folk art based on kneading technique. The boy, either holding the lotus or playing with fish, is very lively, discarding his stereotyped image, and creating modern pottery ceramic work with national style. In addition, Chimpanzee ("Fig. 2") and Snow Leopard created by Zhou Guozhen seek for variation of art based on traditional coil method, which strengthen subjective consciousness and aesthetic imagination. Hou Xiangxiang once commented that "coarse material makes freehand brushwork of Zhou Guozhen more applicable. Such work conveys simple feeling and bold spirit, which makes people feel more profound, primitive, clumsy, pure beauty." ${ }^{3}$ Both of them are based on local art and show the innovative spirit of western art through creations expressing local feelings. Zhu Legeng integrates ceramic art with installation art. His large thematic mural paintings, such as Mirror Image of Sky and Water, Bloom of Life and Imagination of Time and Space, achieve the harmony of environment, decoration and people through the texture of ceramics, reflecting traditional Oriental aesthetics.

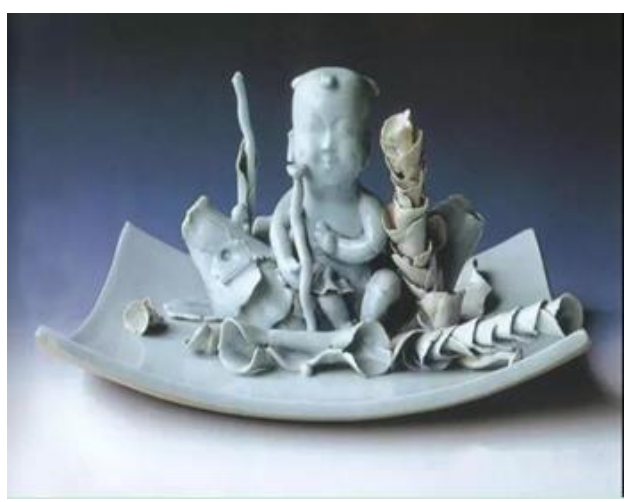

Fig. 1. Century Doll by Yao Yongkang.

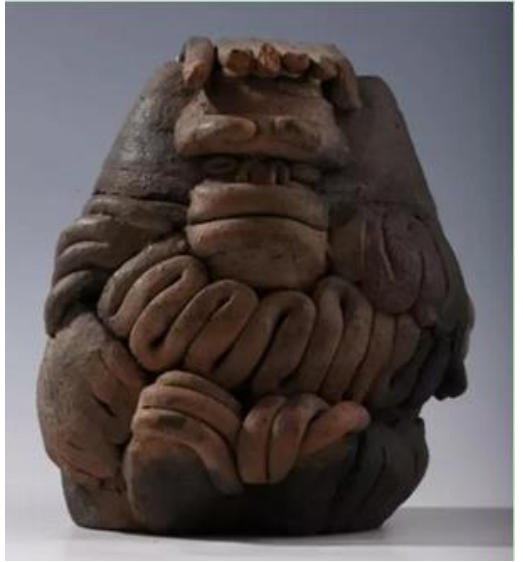

Fig. 2. Chimpanzee by Zhou Guozhen.

Sculpture, 2011.
In terms of material and language, modern Chinese ceramics influenced by traditional Chinese culture are natural and unrestrained, with no persistent pursuit of simulation and deliberate depiction of objects, striving to highlight the humanistic spirit and emotional expression of the works. The modern ceramic art in the West impresses the audience visually, innovating the use of material and language with obvious beauty in form. Modern ceramic creation in the West excels in exploring the original properties of materials, which is taken as an expression medium of artistic language, thus exploring the potential of materials. While China employs the properties of the materials to show the creator's consciousness and spirit dynamics, which is a far cry from Western pursuit of material breakthroughs. The works of Dutch ceramist Paula Bastiaansen ("Fig. $3 ")$ look orderly and graceful. She skillfully adopts the toughness of the soil to realize light, thin and brittle, and materials are taken to directly convey her ideas to the audience. Her themes are "fragility, weightlessness, transparency, rhythm and movement". Mr. Samusa's Walking ("Fig. 4") by Japanese Kazuo Yagi (やぎかずお ) denies the "physical property" of objects to the core, separating ceramics from practical objects and purely expressing the beauty of ceramic materials. Zhou Guozhen, another pioneer of modern Chinese ceramic art, further explored the freehand artistic pursuit and creation technique of Chinese painting with rough clay, pouring plain feeling and bold spirit, and making people feel more profound, primitive, clumsy, and pure beauty.

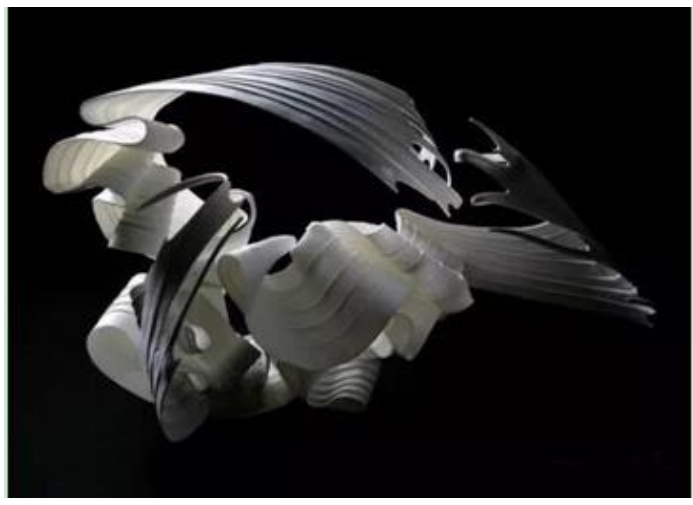

Fig. 3. Rhythm and Beat by Paula Bastiaansen. 


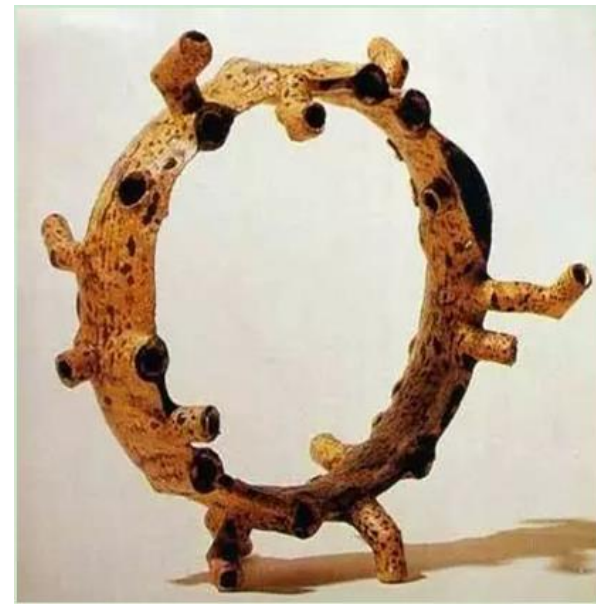

Fig. 4. Mr. Samusa's Walking by Kazuo Yagi (やぎかずお).

In the aspect of aesthetic, the ceramic aesthetic of different countries differs. Japanese ceramics are very simple. They appreciate the simplicity of folk utility. Ancient Chinese paintings emphasize on artistic conception, leaving an empty space for the viewer to imagine and think. Western painting pays attention to realism, and the physical beauty of objects, pursuing similarity in form. Chinese modern ceramic art takes nature as theme, allowing the viewer to blend in with nature and unlock his own consciousness and initiative. The Chinese hold that man and nature are in harmony and unity, and that man is a mere being in nature. The aesthetic entry point of moral angle, and the subjective initiative of human are emphasized. As the old saying goes, 能尽人之性，则能尽物之性；能尽物之性则可以赞天地之 化育; 可以赞天地之化育，则可以与天地参矣 (He who can fully realize his own nature can fully realize the nature of others. He who can fully realize the nature of others can fully realize the nature of all things. He who can realize the nature of all things can help heaven and earth to nurture things. He who can help heaven and earth to nurture things can be juxtaposed with the heaven and the earth.), the artistic language of imagination and metaphor in aesthetic consciousness endows the audience more profound aesthetic pleasure. Modern ceramic art in the West expresses independent nature, which brings concrete and direct aesthetic feeling to the viewer, but also objectively restricts free thinking. Modern ceramic art in China and the West with a new artistic language is standing on the historical stage. Despite their distinction in expression form, content and spiritual appeal, they are all attracted by the linguistic charm of ceramic materials, and modern ceramic art is also winning more favor. All forms of art are justified. It is much easier to understand Chinese ceramics combined with the historical background. However, ceramic art of different ages around the world also share features. The United States and Japan are crucial to the development of modern ceramics.
They enjoy their own history, laws, etiquette and norms. Modern and contemporary art originated in the West and entered modern civilization earlier than China. Modern ceramic art in China still face issues. First, the gap between "tradition" and "modernity". It's hard to escape hyperventilation about the relationship between "tradition" and "modernity". Only by clarifying such relationship can ceramic art truly transform from "tradition" to "modernity". Secondly, the limitation of communication and acceptance. Modern ceramic art in China has not yet won extensive public attention, which cripples its market expansion. Third, the divorce of theory from practice. Unlike Chinese painting, calligraphy, literature and other fields of art, modern ceramic art seriously lacks the support of theoretical works. It's imperative to solve these issues that otherwise would hamstrings the growth of modern ceramic art. After putting things right in the 1980s and 1990s, Chinese ceramic art developed smoothly in many fields. The exploration of diverse, complex and mysterious form is the development trend of modern ceramic art in the future. The current situation of the diversification of modern art should also be recognized. The artistic works of different countries and nationalities and their different styles should be understood in the deepening international exchanges. To seize the development opportunities and face up to the challenges is strategic decision to promote Chinese modern culture and art to the world, which is also the sacred mission and responsibility of Chinese artists.

\section{DESIGN PRACTICE}

\section{A. Design thinking}

According to Overview of Modern Ceramic Art in the World by Bai Ming, "modern ceramic art refers to a form of work in which artists make use of ceramic materials or take ceramic materials as the main creative media to express modern people's ideal, personality, emotion, psychology, consciousness and aesthetic value without focusing only on traditional practical quality. Such aesthetic value excavates not the objective world, but the inner world of modern denizen. It attaches importance to new expression methods and forms, and visualizes such techniques as implication, metaphor, symbol, association and image to show the train of people's consciousness and their multiple cognition of the world and society." 4 Based on the existing understanding, the authors hold that modern ceramic art, as a new art form, should break away from the shackles of traditional emphasis on practicality and serve as carrier for modern people to express their inner feelings, vision and ideas. The authors in the stage of

Bai Ming. Overview of Modern Ceramic Art in the World [M]. Nanchang: Jiangxi Fine Arts Publishing House, 1999.01. 
further study hope to express inner longing for personal mastery through works.

\section{B. Design concept}

According to Cambrian Period ("Fig. 5" and "Fig. 6"), individuals are all volcanoes before they realize their self-worth. There is a blazing fire hidden under the surface of calmness. Only by erupting can they be liberated and become their true selves. The series of work takes part of dormant volcano is as subject of displaying. The ceramic and lacquer are combined together, and the firing method of Raku is employed to interpret the art of fire and earth. The mysterious and steady carbon black echoes with the warm and bright red, expressing the creative idea of awakening the explosive power and realizing personal mastery. The work is named after the Cambrian period during the explosion of life, and highlights that the explosion brought not ruin but rebirth.

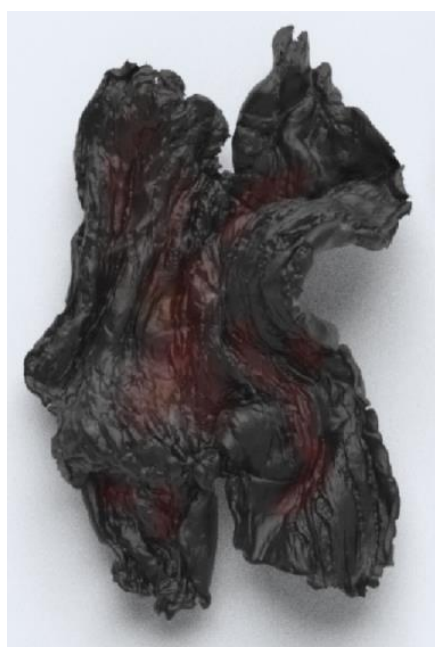

Fig. 5. Cambrian Period (1).

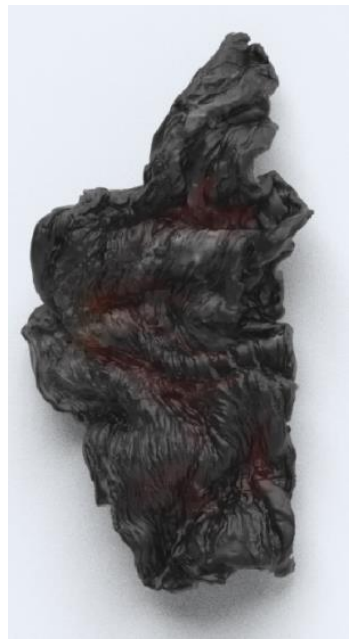

Fig. 6. Cambrian Period (2).
Dialogue between Black and White ("Fig. 7" and "Fig. 8") demonstrates the ancient philosophy that "all things are mutually reinforcing", which corresponds to law of the unity of opposite, the essence and core of materialist dialectics in modern philosophy. The work is inspired by diagram of the universe, the traditional Chinese culture, with black and white the only colors. The varied texture and color contrast are taken to express the "law of unity of opposites". The title Dialogue between Black and White highlights the theme of the work: things are not zero-sum, but covers many aspects. Traditional culture should also be understood from multiple angles, and criticized, inherited and applied in modern society.

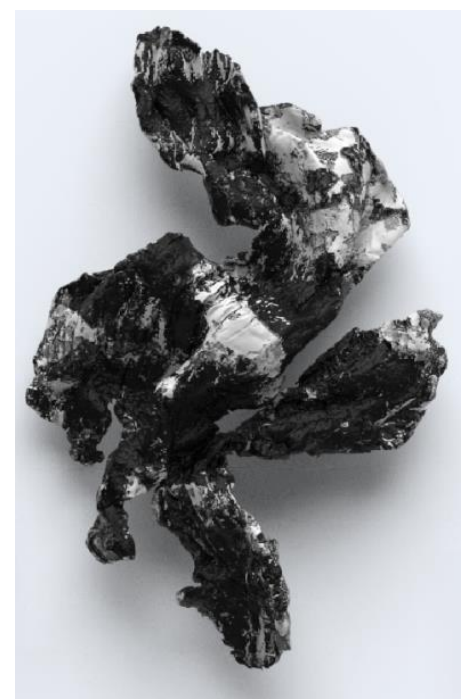

Fig. 7. Dialogue between Black and White (1)

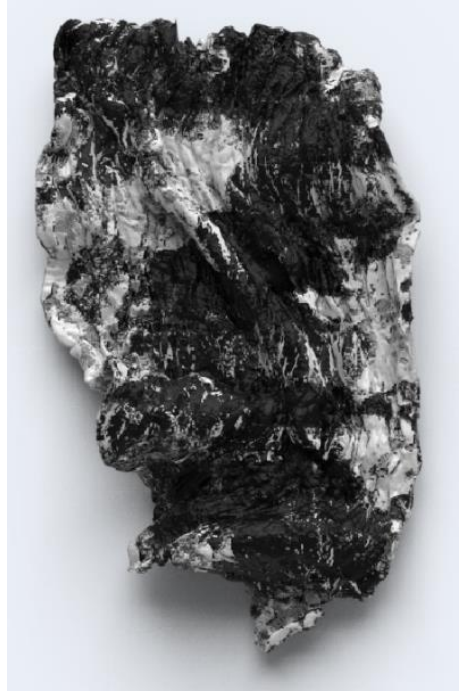

Fig. 8. Dialogue between Black and White (2) 


\section{CONClusion}

The contrast of cultural genes and historical background of ceramic art in China and the West leads to their totally varied paths. It is worth noting that the difference between East and West is manifested in wide and universal trend, which not necessarily results in stark departure. Modern art should enjoys not only general character shared across the world, but also features of national style. The modern ceramic art which abandons the traditional context will be deprived of solid foundation, like water without a source and a tree without roots. Chinese modern ceramics can hardly break out of traditional barriers without the stimulation and enrichment of western culture. Exchanges can make good for deficiency. However, same form and landscape resulted from blending of eastern and western culture through exchange is unacceptable. Therefore, Chinese modern ceramic art should embark on an inclusive and diversified development path with Chinese characteristics based on appeals of the era, while immersing itself in the nourishment of national culture and excellent culture of the world.

\section{References}

[1] Zhu Legeng. A collection of contemporary ceramics [M]. Beijing: Beijing Times Chinese Press, 2015.05.01. (in Chinese)

[2] Hou Xiangxiang. Collection of Modern Ceramic Art Works by Zhou Guozhen [M]. Beijing: Culture and Art Publishing House, 2011.11. (in Chinese)

[3] Zhang Yao. Modern Ceramic Art Research [M]. Changsha: Hunan University Press, September 2006. (in Chinese)

[4] Zuo Zhengyao. The Development of Modern Chinese Ceramic Art $[\mathrm{M}]$. Changsha: Hunan Fine Arts Publishing House, 2003.01. (in Chinese)

[5] Yu Yong. Contemporary Appearance of Ceramics in America [M]. Nanchang: Jiangxi Fine Arts Publishing House, 2012.12. (in Chinese)

[6] Bai Lei, Bai Ming. "Contemporary Ceramic Art in China [M]. Nanchang: Jiangxi Fine Arts Publishing House, 2003. (in Chinese)

[7] Liu Qiaoyan. From Rebellion to Return: Exploration and Analysis of Chinese Modern Ceramic Craft from 1984 till Now [D]. Shandong: Shandong University of Arts, 2014. (in Chinese)

[8] Yang Yujie. Rebellion and Reconstruction: The Study on the Creative Process of Chinese Modern Ceramic Art [D]. Beijing: China National Academy of Arts, 2015. (in Chinese) 